\title{
Formulated diets for giant Chilean frog Calyptocephalella gayi tadpoles
}

\author{
Pedro H. Toledo ${ }^{1,2}$, Ricardo Suazo ${ }^{3}$, and Maria T. Viana ${ }^{4}$ \\ ${ }^{1}$ Departamento de Acuicultura, Facultad de Ciencias del Mar, Universidad Católica del Norte. Larrondo \\ 1281, Coquimbo, Chile. \\ ${ }^{2}$ Centro de Estudios Avanzados en Zonas Áridas (CEAZA). Larrondo 1281, Coquimbo, Chile. \\ ${ }^{3}$ Cultivos Marinos Chiloé S.A. Ruta 5 Sur, Km. \#1105, Ancud, Chile. \\ ${ }^{4}$ Instituto de Investigaciones Oceanológicas, Universidad Autónoma de Baja California. km 107 Carretera \\ Tijuana-Ensenada, Ensenada Baja California, Mexico.
}

\begin{abstract}
P.H. Toledo, R. Suazo, and M.T. Viana. 2014. Formulated diets for giant Chilean frog Calyptocephalella gayi tadpoles. Cien. Inv. Agr. 41(1): 13-20. In this study, we conducted an experiment to evaluate the overall effect of novel diets on the growth, metamorphosis and survival of tadpoles of the endangered giant Chilean frog Calyptocephalella gayi (previously known as Caudiverbera caudiverbera) to evaluate the potential of this species for culture and repopulation purposes. Using fishmeal as the main protein source with a substitution of either scallop viscera or Spirulina meal, three treatments were formulated to contain similar amounts of protein and energy. The experiment was run for 75 days, after which the tadpoles showed no significant differences among treatments in terms of their growth or survival. This is the first study to report positive effects of different diets on the growth and survival of tadpoles of the giant Chilean frog. Therefore, it might be possible to extend the farming of Calyptocephalella gayi for human consumption and repopulation. Nevertheless, more efforts are needed to understand their nutritional requirements to formulate appropriate diets for this endangered frog.
\end{abstract}

Key words: Artificial diet, nutrition, protein sources, Spirulina meal, survival.

\section{Introduction}

According to the Food and Agriculture Organization (FAO), the number of species used in aquacultural systems increased to 541 in 2010 , including 327 finfish, 102 mollusk, 62 crustacean,

Received October 8, 2013. Accepted January 29, 2014. Corresponding author: ptoledo@ucn.cl
9 aquatic invertebrate, 35 algal and 6 amphibian and reptile species (FAO, 2012). This increase in production has resulted in improved nutritional and dietary knowledge and new technologies, which have enabled the increasing demand for food from such production to be met and an increasing number of species to be supported. Therefore, there is a constant need to produce high-quality and nutritional products for use in aquacultural systems. 
In particular, the culturing of edible frogs around the world, including Lithobates catesbeiana, L. clamitans, L. aurora, L. pipiens, L. tigrina, L. hexadactyla, L. magna and L. vittigera, has increased, with a total production of $378,000 \mathrm{t}$ in 2010 (FAO, 2010). The main producers are China, Brazil, Mexico and Thailand, with L. catesbeiana being the most prevalent species. However, despite their economic importance, research on these species is limited (Silva de Castro et al., 2012), and most of the available references focus on their feeding behavior, with little information available regarding their nutritional requirements. Therefore, it is difficult to improve the culturing of these species from a dietary perspective.

The giant Chilean frog Calyptocephalella gayi, which can weigh up to $0.5 \mathrm{~kg}$ and lives in lakes and rivers from the Coquimbo to Los Lagos region in Chile (Acuña, 1996), is currently classified as endangered. After mating, the female lays eggs that hatch into tadpoles $6-8 \mathrm{~mm}$ in length (Castañeda et al., 2006). The tadpole has internal gills, a powerful adhesive organ, a functional mouth after $48 \mathrm{~h}$ post hatching and a vigorous tail for swimming. Plankton and detritus are the main food sources of the tadpoles, which become carnivorous once they reach the adult stage. An analysis of the stomach contents of $C$. gayi tadpoles showed their diet to be comprised of mainly benthonic microalgae, such as diatoms (Parra et al. 1974). Altig and McDearman (1975) observed that food retention in the digestive tract of tadpoles is short with a possible frequent ingestion rate. Food is acquired via filtration through the pharynx cavity and scratching the habitat surface (Parra et al., 1974). There are a few currently unpublished reports of tadpoles achieving good growth rates with high protein formulated diets, whereas other studies have reported a complicated dietary management for this species, which appears to prefer live prey (Carmona et al., 1996). Castañeda et al. (2006) studied the digestive physiology of C. gayi tadpoles utilizing fresh vegetables and rat pellets.
The use of formulated diets is important to support the continuous and specific nutritional requirements of frogs (Garcia, 1987; Tacon, 1990). Most commercially important species are carnivores, for which fishmeal is the most utilized protein source; however, fishmeal is not a sustainable resource for use on a commercial scale, especially in aquaculture (Tacon and Metian, 2009). Therefore, the study of alternative protein sources for use in aquaculture is required because it could enable the culturing of new species for commercial and/or repopulation purposes. Although the giant Chilean frog tadpole shows omnivorous feeding behavior (Martinez et al., 1994), other reports suggest that high levels of dietary protein could be required (Olvera-Novoa et al., 2007). Such information would enable this endangered species to be cultured, either commercially or for repopulation programs.

In this study, we evaluated the effects of diets with fishmeal as the main protein source and scallop viscera or Spirulina meal as partial substitutes. Our results will be useful for evaluating the overall performance of such diets for use by this endangered species.

\section{Materials and methods}

\section{Formulated diets}

Three diets were formulated to contain similar amounts of protein and energy (Table 1). The FM diet contained fishmeal as the principal protein source; the FMV diet contained $11.4 \%$ scallop viscera meal (Argopecten purpuratus) and the FMS diet contained $12.4 \%$ Spirulina meal in substitution of fishmeal. Diets were prepared by mixing the ingredients to produce a homogeneous dough with $30 \%$ moisture content. Cold extrusion of the dough through a meat grinder produced pellets $6 \mathrm{~mm}$ in diameter. The pellets were then crushed and stored in hermetic plastic bags at $-20{ }^{\circ} \mathrm{C}$ until use. 


\section{Experimental conditions}

A total of 126 giant Chilean frog tadpoles (240 days old; $10.99 \pm 1.50 \mathrm{~g}$ mean body weight) were used. The experimental units were comprised of nine buckets (15 L total volume) in which groups of 14 tadpoles were randomly distributed and fed the experimental diets in triplicate for a total of 75 days. The tadpoles were maintained under constant open flow $\left(12 \mathrm{~L} \mathrm{~h}^{-1}\right)$ and a mean water temperature of $17.5 \pm 1.3{ }^{\circ} \mathrm{C}$. The tadpoles were weighed every 15 days using a digital bal-

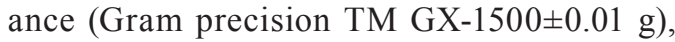
and their metamorphosis stage was evaluated daily. Experimental diets were added twice a day $(10: 00$ and $18: 00 \mathrm{~h}$ ) to the buckets at a rate of $8 \%$ of the biomass of the tadpoles. Feed intake (F) was determined using Equation 1 as reported by Gomez-Montes et al. (2003):

$$
\mathrm{F}=[(\mathrm{G} * \mathrm{~S}) / 100]-\mathrm{R}
$$

where $\mathrm{G}$ is the amount of feed offered (g), S is the percentage of feed recovered from empty buckets without tadpoles, representing the water stability of the diets, and $\mathrm{R}$ is the uneaten feed $(\mathrm{g})$ remaining in the buckets containing the tadpoles.

Food efficiency (FE) was then calculated using Equation 2:

$\mathrm{FE}=$ wet weight gain $(\mathrm{g}) /$ dry feed consumed $(\mathrm{g})$

After the experimental trial, tadpole growth was expressed as the percentage of total weight gain or specific growth rate (SGR) using Equations 3 and 4, respectively:

Weight gain $(\%)=($ final weight-initial weight $\times 100) /$ initial weight

$\mathrm{SGR}=\left(\ln \mathrm{w}_{\mathrm{t}}-\ln \mathrm{w}_{\mathrm{i}} \times 100\right) / \mathrm{t}$

Table 1. Ingredients and chemical analysis of formulated diets for Calyptocephalella gayi tadpoles.

\begin{tabular}{|c|c|c|c|}
\hline \multirow[b]{2}{*}{ Ingredients } & \multicolumn{3}{|c|}{ Experimental diets ( $\%$ of dry matter) } \\
\hline & FM & FMV & FMS \\
\hline Fishmeal $^{1}$ & 53.2 & 42.75 & 42.35 \\
\hline Viscera meal of $A$. purpuratus ${ }^{1}$ & 0 & 11.4 & 0 \\
\hline Spirulina meal $^{2}$ & 0 & 0 & 12.4 \\
\hline Modified corn starch & 40.1 & 39.24 & 39 \\
\hline Fish oil ${ }^{1}$ & 3.95 & 3.86 & 3.5 \\
\hline Vitamin $\operatorname{mix}^{3}$ & 1 & 1 & 1 \\
\hline Mineral $\mathrm{mix}^{3}$ & 1 & 1 & 1 \\
\hline Ascorbic acid ${ }^{3}$ & 0.75 & 0.75 & 0.75 \\
\hline \multicolumn{4}{|l|}{ Proximate composition } \\
\hline Total lipids & 9.58 & 10.22 & 8.45 \\
\hline Crude protein & 39.22 & 40.11 & 39.49 \\
\hline Ash & 10.87 & 10.02 & 10.82 \\
\hline $\mathrm{NFE}^{4}$ & 40.33 & 39.65 & 41.24 \\
\hline Energy $\left(\right.$ Kcal g$\left.^{-1}\right)$ & $3.53 \pm 0.13$ & $3.42 \pm 0.09$ & $3.46 \pm 0.08$ \\
\hline \multicolumn{4}{|c|}{$\begin{array}{l}\text { FM, full fishmeal; FMV, diet with } 11.4 \% \text { A. purpuratus viscera meal; FMS, diet with } 12.40 \\
\text { Spirulina meal. } \\
{ }^{1} \text { Provided by Pesquera San José. Coquimbo, Chile. } \\
{ }^{2} \text { Provided by Empresa Chañar Blanco Ltda. Coquimbo, Chile. } \\
{ }^{3} \text { Provided by Veterquimica S.A. Santiago, Chile } \\
{ }^{4} \mathrm{NFE} \text { : nitrogen free extract }=100-(\% \text { crude protein }+\% \text { total lipids }+\% \text { ash }) .\end{array}$} \\
\hline
\end{tabular}


where $\mathrm{w}_{\mathrm{t}}$ is the weight at time $t$, and $\mathrm{w}_{\mathrm{i}}$ is the initial weight.

The metamorphosis rate was estimated daily by the direct counting of tadpoles that had undergone the process.

\section{Chemical analysis}

Formulated diets were chemically analyzed by proximate composition. Crude protein $(\mathrm{CP})$ was determined based on the total nitrogen content of the sample using the Kjeldhal method (AOAC, 2000), multiplying by 6.25 to obtain an estimated value. Total lipids were extracted with a chloroform-methanol solution (2:1v/v) (Folch et al., 1957) and determined gravimetrically. Dry matter percentage was calculated after samples of each diet were dried to $95^{\circ} \mathrm{C}$ until they reached a constant weight. The ash content of the samples was determined by cremating samples for $15 \mathrm{~h}$ at $500{ }^{\circ} \mathrm{C}$; nitrogen-free extract (NFE) was calculated by the difference in proximate composition. The energy of the formulated diets $\left(\mathrm{Kcal} \mathrm{g}^{-1}\right)$ was determined using a calorimeter (Ogama Seiki Co., Ltd).

\section{Statistical analysis}

One-way analysis of variance (ANOVA) was used to evaluate differences among treatments.
Significant differences between groups were determined using Tukey's test and reported as statistically significant with a $\mathrm{P} \leq 0.05$ for the parameters tested. Data expressed as percentages were transformed to arcsine before analysis (Sokal and Rohlf, 1981).

\section{Results and discussion}

The proximate composition showed crude protein, total lipids and energy levels of diets (Table 1), and these were formulated to contain similar amount of protein and energy.

After a 75-day feeding trial, a similar survival rate $(83-90 \%)$ was observed among treatments, and significant differences were not found (one way ANOVA; $F(2,6)=1.0689, \mathrm{p}=0.4008$ ) (Table 2). The metamorphosis rate was 84 to $97 \%$, with no significant differences between the treatments (one way ANOVA; $F(2,6)=4.6290, \mathrm{p}=0.0608$ ). The total weight gain varied from $115 \%$ for tadpoles fed FMV to $99.6 \%$ for tadpoles fed FM. The specific growth rate was from $0.9 \% \mathrm{~d}^{-1}$ for FM and $1.0 \%$ $\mathrm{d}^{-1}$ for FMS and FMV. No significant differences were found in FE among the different diets, with the data varying from 0.84 for FMS to 1.3 for FM.

The aim of this study was to demonstrate the feasibility of culturing tadpoles of the giant Chilean frog with an emphasis on dietary requirements

Table 2. Biological parameters of Calyptocephalella gayi tadpoles fed for 75 days with formulated diets $(n=3)$.

\begin{tabular}{lccc}
\hline & \multicolumn{3}{c}{ Dietary treatments } \\
\cline { 2 - 4 } Parameter & FM & FMV & FMS \\
\hline Initial weight $(\mathrm{g})$ & $11.01 \pm 1.54$ & $11.01 \pm 1.59$ & $10.96 \pm 1.40$ \\
Final weight $(\mathrm{g})$ & $23.63 \pm 1.67$ & $22.83 \pm 1.57$ & $22.63 \pm 3.1$ \\
Weight increase (\%) & $99.61 \pm 0.38 \mathrm{~b}$ & $115.07 \pm 0.08 \mathrm{a}$ & $108.76 \pm 0.16 \mathrm{a}$ \\
Weight growth $\left(\mathrm{g} \mathrm{d}^{-1}\right)$ & $0.17 \pm 0.02$ & $0.16 \pm 0.01$ & $0.16 \pm 0.02$ \\
Specific growth rate (SGR) $\left(\% \mathrm{~d}^{-1}\right)$ & $0.90 \pm 0.17 \mathrm{~b}$ & $1.02 \pm 0.08 \mathrm{a}$ & $0.98 \pm 0.17 \mathrm{ab}$ \\
Food intake (FI) $(\mathrm{g}$ fresh weight) & $0.95 \pm 0.37 \mathrm{~b}$ & $1.40 \pm 0.43 \mathrm{a}$ & $1.52 \pm 0.49 \mathrm{a}$ \\
Food efficiency (FE) & $12.92 \pm 0.79$ & $9.66 \pm 0.49$ & $8.39 \pm 0.43$ \\
Survival (\%) & $83.33 \pm 0.10$ & $90.48 \pm 0.11$ & $83.33 \pm 0.07$ \\
Metamorphosis rate (\%) & $96.97 \pm 3.03$ & $84.51 \pm 4.08$ & $88.38 \pm 3.03$ \\
\hline
\end{tabular}

Values with different superscripts are significantly different $(\mathrm{P} \leq 0.05)$.

FM, full fishmeal; FMV, diet with $11.4 \%$ A. purpuratus viscera meal; FMS, diet with $12.4 \%$ Spirulina meal. 
and composition. This study is the first to report the effects of different protein sources on the growth of tadpoles of the giant Chilean frog in aquaculture conditions. As previously mentioned, there is little published information available regarding the dietary requirements of this species and their effects on tadpole growth and behavior.

Our results demonstrated that tadpoles of the giant Chilean frog were able to ingest formulated diets resulting in a SGR of approximately $1 \% \mathrm{~d}^{-1}$. This SGR is lower than that reported for the tropical bullfrog L. catesbeiana (2.7-3.7\% $\mathrm{d}^{-1}$, Olvera et al., 2007), which is a species that grows at higher temperatures $\left(28^{\circ} \mathrm{C}\right)$ compared with the giant Chilean frog $\left(17^{\circ} \mathrm{C}\right)$. However, the FEs recorded using the experimental diets were better or similar to those reported for the tropical bullfrog (Flores-Nava and Vera-Muñoz, 1999; Olvera et al., 2007, respectively). Feed palatability is an important factor in promoting food ingestion and was easily observed when the giant Chilean frog was fed either the FMV or FMS diets. The feed intake rate increased by almost $50 \%$ in both cases, although no significant differences were found between the three diets. In the wild, frogs are hunters, and palatability should have an important role in increasing food ingestion; however, in aquaculture conditions this does not occur.

Therefore, viscera might be a useful way to stimulate food ingestion. However, based on the FE recorded from diets with the same nutrient composition, the experimental FMV and FMS diets would not be used efficiently by the tadpoles, even if increasing the ingestion rate encouraged growth.

Several reports suggest the need to optimize protein efficiency in frog diets, specifically by knowing the protein requirements of the juvenile stages of different frog species (Carmona-Osalde et al., 1996; Martinez et al., 2004; Olvera-Novoa et al., 2007). Olvera-Novoa et al. (2007) demonstrated that a higher protein content resulted in a higher growth rate. However, diets containing
$58 \%$ protein, as reported by Olvera-Novoa et al. (2007), are neither convenient nor sustainable on a commercial basis. Martínez et al. (2004) tested trout feed on $L$. perezi and obtained lower growth rates using diets containing $54 \%$ protein compared with diets containing $46 \%$ crude protein. This result, which contradicts that of Olvera-Novoa et al. (2007), could be due to the composition of the feed as a whole because trout feed has a high lipid content; however, no information was given regarding the composition or brand of food used in the study used. Nevertheless, the SGRs obtained by Martínez et al. (2004) were lower than expected $\left(0.3-1.0 \% \mathrm{~d}^{-1}\right)$, and high mortality rates were also reported. In the current study, a promising growth rate was obtained when fishmeal was partially substituted with either scallop viscera or Spirulina. The use of fishery by-products and/ or a local source of protein will be important to sustain the aquaculture of this species. Although Spirulina has been shown to have good properties as a protein source for a wide range of organisms, its inclusion in artificial diets is limited, owing to its availability and cost (Habib et al., 2008; Olvera-Novoa et al., 1998).

Currently, Spirulina is produced in Chile commercially at low cost; therefore, its use can be recommended. Moreover, viscera from scallop are not generally used, but much is produced and discharged by the aquaculture industry, leading to environmental problems. In the current study, only $20 \%$ of fishmeal protein was replaced either with scallop viscera or Spirulina; therefore, more studies are required to determine the maximum level of fishmeal replacement and the related nutrient requirements to be able to replace fishmeal completely. In the present work, the tadpoles were provided food at a rate of $8 \%$ of their total biomass; however, only $1.0-1.5 \%$ was ingested. Therefore, studies are required to optimize the feeding strategy to avoid feed waste. De Castro et al. (2012) demonstrated that growth rate and digestibility both improved when animals were fed 46 meals $\mathrm{d}^{-1}$ through automatic feeders. Therefore, changing the feeding regimes and optimizing the protein content by substituting fishmeal 
with other feed will be crucial to sustaining commercial cultures of the giant Chilean frog. In addition, the FE failed to show significant differences among dietary treatments, most likely because of large sample variation. However, food intake rate is a difficult parameter to measure in aquaculture, owing to food stability and waste.

The rate of metamorphosis obtained here was slightly higher in tadpoles fed the FM diet; however, the results were not statistically significant (one way ANOVA; $\mathrm{F}(2,6)=4.6290, \mathrm{p}=0.0608)$, although they were high relative to reports from other amphibian species (Martínez et al., 1994; Carmona et al., 1996).

The culture density of this trial was 1.1 tadpoles $\mathrm{L}^{-1}$, which is considered by Flores-Nava and VeraMuñoz (1999) to be a low density for L. catesbeiana tadpoles. Therefore, no density limitations could be expected to reduce growth.

We can conclude that giant Chilean frog tadpoles can be reared efficiently with diets containing either fishmeal alone or fishmeal with a partial substitution of viscera from scallops or Spirulina. However, more studies are required to determine the amount of fishmeal that can be substituted that provides the necessary nutrients without affecting palatability. The giant Chilean frog tadpoles show potential for commercial or repopulation activities due to their endangered species status. Although the SGR was generally lower than that obtained for the tropical bullfrog, experiments should be conducted at different temperatures to determine whether temperatures above $17^{\circ} \mathrm{C}$ would result in improved SGR.

\section{Acknowledgments}

This work was supported by grant FONDEFHUAM AQ04I1018. We thank the Pesquera San José and Chañar Blanco from Coquimbo-Chile companies for donating raw material and M.Sc. Alonso Vega for statistical analysis support.

\section{Resumen}

P.H. Toledo, R. Suazo, y M.T. Viana. 2014. Dietas formuladas para renacuajos de la rana gigante chilena Calyptocephalella gayi. Cien. Inv. Agr. 41(1): 13-20. Este es el primer estudio de alimentación con dietas formuladas para evaluar la factibilidad y su efecto en el crecimiento, metamorfosis y supervivencia de renacuajos de la rana grande chilena Calyptocephalella gayi (anteriormente Caudiverbera caudiverbera) y valorar el potencial de esta especie en peligro, para desarrollar la acuicultura y la repoblación. Se realizaron tres tratamientos con dietas que contenían similares niveles de proteína y energía, utilizando harina de pescado como principal fuente proteica y con sustituciones parciales con harina de víscera de ostión y Spirulina. El experimento duró 75 días, en el transcurso de los cuales los renacuajos no mostraron diferencias significativas entre los tratamientos en términos de crecimiento y supervivencia. Este es el primer estudio que reporta efectos positivos de dietas formuladas sobre el crecimiento y supervivencia de renacuajos de la rana gigante chilena en cautiverio. Por lo tanto, se concluye que es factible cultivar, utilizando alimento formulado, renacuajos de Calyptocephalella gayi. Sin embargo, se requiere realizar más esfuerzos y profundizar en el conocimiento de los requerimientos nutricionales para generar una dieta apropiada para esta especie en peligro.

Palabras clave: Dieta balanceada, fuentes de proteína, harina de Spirulina, nutrición, supervivencia. 


\section{References}

Acuña, L. 1996. Efecto de diferentes dietas sobre el crecimiento de larvas de Caudiverbera caudiverbera_durante meses de invierno en la región del Bío-Bío. Memoria para optar al título de Médico Veterinario. Universidad de Concepción, Concepción, Chile. 77 pp.

Altig, R., and W. McDearman. 1975. Percent assimilation and clearance times of five anuran tadpoles. Herpetologica 31:67-69.

AOAC - Association of Official Analytical Chemists. 2000. Official methods of analysis, 17th edn. AOAC, Gaithersburg.

Carmona-Osalde, C., M.A. Olvera-Novoa, M. Rodríguez-Serna, and A. Flores-Nava. 1996. Estimation of the protein requirement for bullfrog (Rana catesbeiana) tadpoles, and its effect on metamorphosis ratio. Aquaculture 141:223-231.

Castañeda, L.E., P. Sabat, S.P. Gonzalez, and R.F. Nespolo. 2006. Digestive plasticity in tadpoles of the Chilean giant frog (Caudiverbera caudiverbera): Factorial effects of diet and temperature. Physiological and Biochemical Zoology 79(5):919-926.

De Castro, C.S., C.A. Agostinho, D. Argentim, J. Sversut de Alexandre, L.C. de Oliveira, R.M. Ramalho de Sousa, and Pedro de M. Padilha. 2012. Feed digestibility and productive performance of bullfrogs fed in high and low frequency. Aquaculture 326-329:123-128.

FAO - Food and Agriculture Organization. 2010. Producción acuícola mundial. Departamento de Pesca y Acuicultura. Available online: http:// www.fao.org/fishery/statistics/global-aquaculture-production/es (Website accessed April 20, 2013)

FAO - Food and Agriculture Organization. 2012. The state of world fisheries and aquaculture. FAO Fisheries and Aquaculture Department. Food and agriculture organization of the United Nations. Rome, Italy. 209 pp.

Flores-Nava, A., and P. Vera-Muñoz. 1999. Growth, metamorphosis and feeding behavior of Rana catesbeiana Shaw 1802 tadpoles at different rearing densities. Aquaculture Research 30:341-347.
Folch, B.J., M. Lees, and G.H.S. Sloanestanley. 1957. A simple method for the isolations and purification of total lipids from animal tissues. Journal of Biological Chemistry 226:497-509.

García, M. 1987. Formulación de dietas experimentales y piensos comerciales. In: Espinoza del Montero, J. and U. Labarta (eds.). CAYCIT. Alimentación en acuicultura. Industrias gráficas. Madrid, España. p. 23-57.

Gómez-Montes, L., Z. García-Esquivel, L.R. D’Abramo, A. Shimada, C. Vásquez-Peláez, and M.T. Viana. 2003. Effect of dietary protein: energy ratio on intake growth and metabolism of juvenile green abalone Haliotis fulgens. Aquaculture 220:769-780.

Habib, M.A.B., M. Parvin, T.C. Huntington, and M.R. Hasan. 2008. A review on culture, production and use of Spirulina as food for humans and feeds for domestic animals and fish. FAO Fisheries and Aquaculture Circular No 1034. Rome, Italy. 33 pp.

Martínez, I., M.P. Herrez, and R. Alvarez. 1994. Response of hatchery-reared Rana perezi larvae feed different diets. Aquaculture 128:235-244.

Martinez, I.P., M. Real, and R. Alvarez. 2004. Growth of Rana perezi Seoane, 1885 froglets fed on diets with different nutrient compositions. Aquaculture 241:387-394.

NRC - National Research Council. 2011. Nutrient Requirements of Fish and Shrimp. Committee on Nutrient Requirements of Fish and Shrimp Board on Agriculture and Natural Resources Division on Earth and Life Studies. National Research Council of the National Academies. The National Academies Press Washington DC. 363 pp.

Olvera-Novoa, M.A., J. Dominguez-Cen, and L. Olvera-Castillo. 1998. Effect of the use of the microalga Spirulina maxima as fishmeal replacement in diets for tilapia Oreochromis mossambicus (Peters) fry. Aquaculture Research 29:709715.

Olvera-Novoa, M.A., V.M. Ontiveros-Escutia, and A. Flores-Nava. 2007. Optimum protein level for growth in juvenile bullfrog (Rana catesbeiana Shaw, 1802). Aquaculture 266:191-199.

Parra, O., P. Rivera, M. González, and I. Hermosilla. 1974. Análisis de la flora algológica del con- 
tenido estomacal de los estados larvarios de Caudiverbera caudiverbera (Linnaeus, 1758) (rana grande chilena). Boletín de la Sociedad de Biología de Concepción 48:85-89.

Sokal, R.R., and F.J. Rohlf. 1981. Biometry: Principles and practice of statistical in biological research. W.H. Freeman and Co. San Francisco, USA. 776 pp.
Tacon, A. 1990. Standard methods for the nutrition and feeding of farmed fish and shrimp. Argent Laboratories Press Washington, USA. $207 \mathrm{pp}$.

Tacon, A.G.J., and M. Metian. 2009. Fishing for feed or fishing for food: increasing global competition for small pelagic forage fish. Ambio 38:294-302. 